\title{
Digital Method for Verifying Archaeological Hypotheses. Medieval Stronghold Under Pułtusk Castle
}

\author{
KRZYSZTOF KOSZEWSKI, SEAWOMIR KOWAL, JAN SEYK and STEFAN WRONA, \\ Warsaw University of Technology, Poland
}

\begin{abstract}
This paper describes the process of cooperation between architects and archaeologists initiated in 2012 and finalized as the virtual reconstruction of the medieval proto-urban site in Pultusk, Poland. The result was a digital model of urban tissue based on parametric methods supported by 3D printing. This paper describes the process of organization of digitized analog data, enriched with experts' knowledge, which results in a procedural model of the settlement. The effects ended not only with digital and physical 3Dprinted models but also with a set of conclusions confirming the usefulness of such methods in scientific research concerning the interpretation of archaeological relicts in situ, when not all information is available. Both archaeological practice and the process of architectural reconstruction confirm that the reliability of scientific research and the regime of logical reasoning are independent of the technology used. However, they may be effectively supported by new methods and tools.
\end{abstract}

Key words:

Procedural modeling, Virtual reconstruction, Virtual archaeology, 3D printing

SDH Reference:

Krzysztof Koszewski et al. 2017. Digital Method for Verifying Archaeological Hypotheses. Medieval

Gord Under Pultusk Castle. SDH, 1, 2, 444-455.

DOI : $10.14434 /$ sdh.v1i2.23412

\section{INTRODUCTION}

This paper describes interdisciplinary cooperation between architects and archaeologists during the virtual reconstruction of the Medieval stronghold ( $13^{\text {th }}-14^{\text {th }}$ Century) located in Pultusk in the NorthEastern part of central Poland. In the 1970's, archaeologists conducted excavations under the Pultusk town castle courtyard. They found the remains of wooden huts of a Medieval settlement. Analysis let the scientists formulate the thesis that these artifacts represented an example of a proto-city. In the 1990s, an attempt was made to verify this reasoning by making virtual models using surface and solid modeling. It soon turned out that effects were limited to spectacular photorealistic renderings only. Even at that time, this was not satisfactory since the main result was just an appealing image,

Authors' address: Krzysztof Koszewski, Sławomir Kowal, Jan Słyk and Stefan Wrona, Faculty of Architecture, Warsaw University of Technology, Koszykowa 55, 00-659 Warsaw, Poland; email: (krzysztof.koszewski slawomir.kowal jan.slyk stefan.wrona)@pw.edu.pl

Permission to make digital or hardcopies of part or all of this work is granted without fee according to the open access policy of SDH.

(C) 2017 SDH Open Access Journal

Studies in Digital Heritage, Vol. 1, No. 2, Publication date: December 2017 
and areas where there was no archaeological data remained a void. Paradoxically, such images were one of the reasons which raised interest in archaeological virtual reconstruction [Haegler et al. 2009].

Lack of tools verifying archaeological hypotheses in a satisfactory way and the emergence of new tools and methods, including procedural modeling that could handle the challenge of uncertainty, led to new research beginning in 2012.

\section{THE SITE}

The Medieval stronghold in Pultusk is located on a hill surrounded by the river Narew and swampy areas. It was built up with many consecutive layers, including the castle, which is still in use. Excavations conducted during 1976-1985 were possible only due to massive renovation and adaptation of the castle and were only in the areas included in this process. In effect, more than $60 \%$ of the possible settlement area remained unexcavated (Fig. 1).

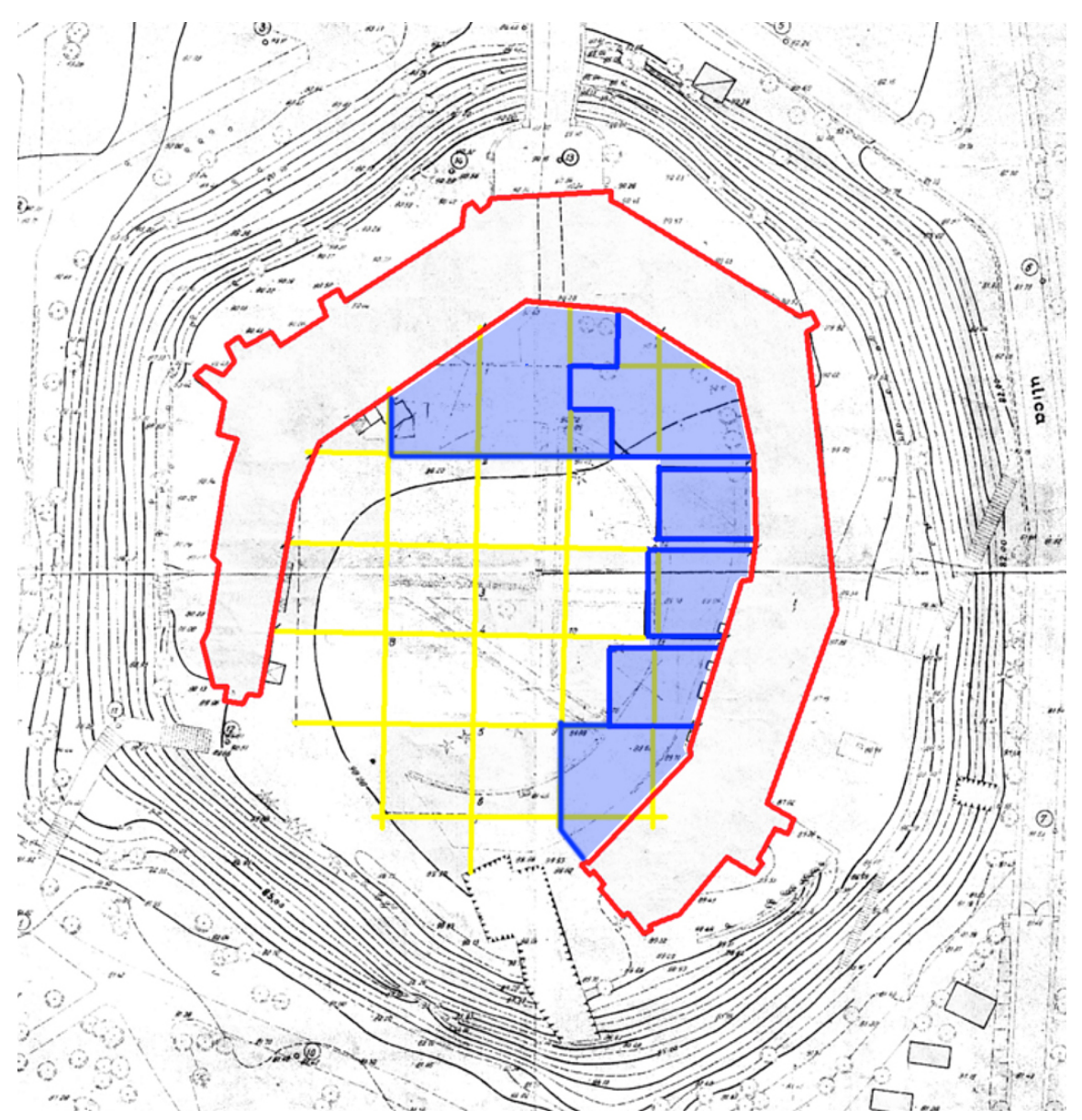

Fig. 1. Pultusk Castle: site plan of archaeological excavations. Red: castle; yellow: geodetic grid; blue: excavation area. 
However, wooden elements of huts and the street layout were extremely well preserved due to the high level of groundwater, which prevents air penetration (Fig. 2). All elements were layered, which facilitated site stratigraphy. After ten years of excavations, all exposed structures and artifacts were analyzed and drawn, which, after another 30 years, resulted in massive analogue documentation, including 470 plans of structures in scale 1:20 and over 150 precise hut descriptions [Gołembnik et al. 1997].

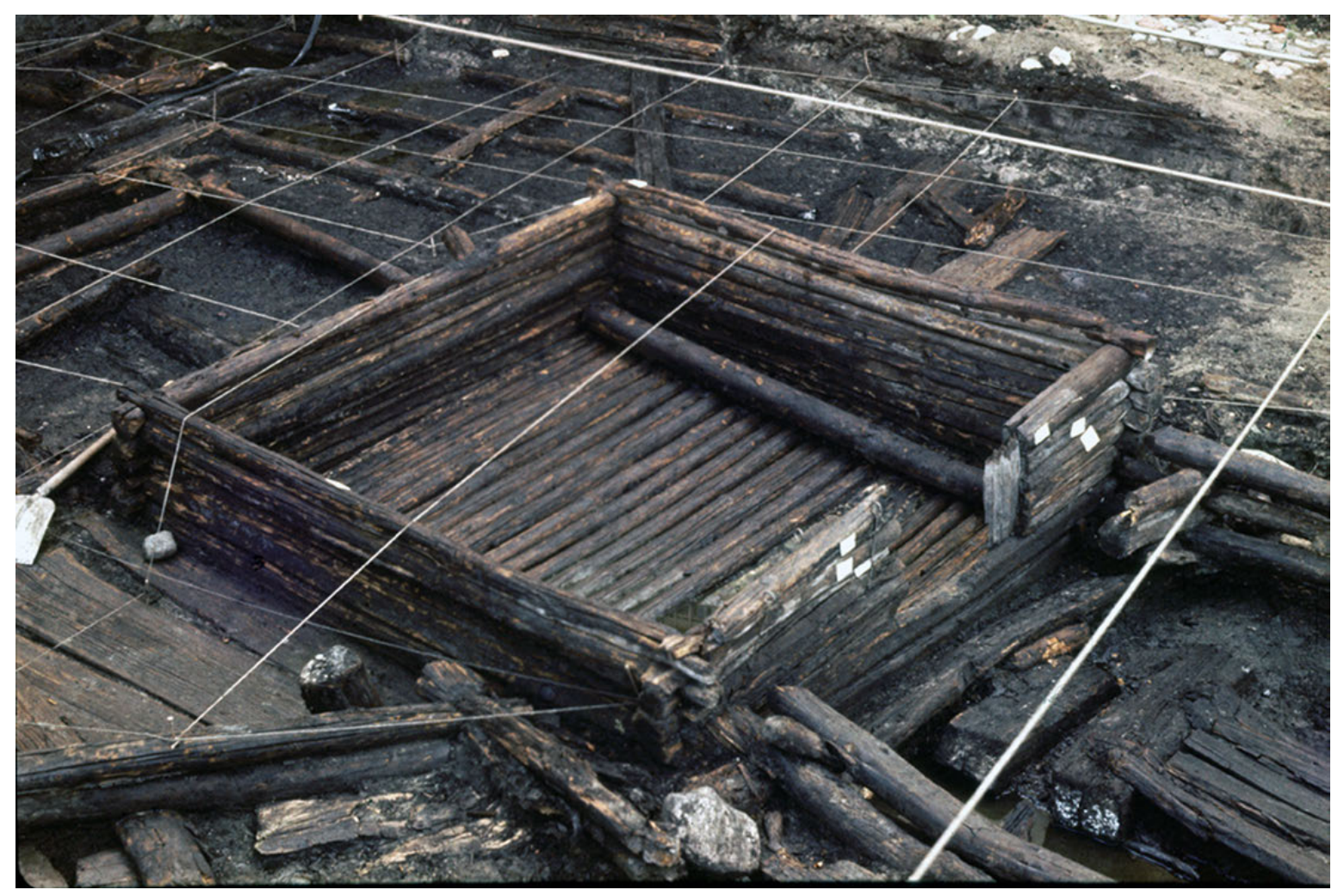

Fig. 2. Relics of wooden structures discovered during excavations. Some of them were in very good condition.

\section{DIGITAL-MODEL OF THE SITE}

There has been extensive research on the application of 3D digital modeling techniques in documenting archaeological sites during past 20 years, starting in the early 90s [Reilly 1991], with significant growth of interest during past decade [Reu et al. 2013]. Most of these methods employ image-based 3D modeling [Remondino and El-hakim 2006] applied on-site and on found artifacts, resulting in dense point-clouds. However, the case of Pultusk is different, since previously made analogue documentation has had to be digitized and used as a base for 3D model creation. Stratigraphy delivered from excavated material allowed identification of 17 layers of the settlement spanning 140 years. This data was digitized, first in 2D planes, where each drawn layer of artifacts was turned into a vector drawing. Then, $\mathrm{Z}$ coordinate depth was applied using data recorded as 
elevation measurements on the drawings of the plans. This procedure allowed recreation of a certain state of the landscape, dating back to the layer with the most huts preserved (layer 4). The rest of the area was recreated using land cross sections derived from archaeological and geological data. The ground was cut with horizontal planes to create closed level curves. In the last step, points recorded by archaeologists were created on these curves as the basis for a digital 3D terrain model (Fig. 3).

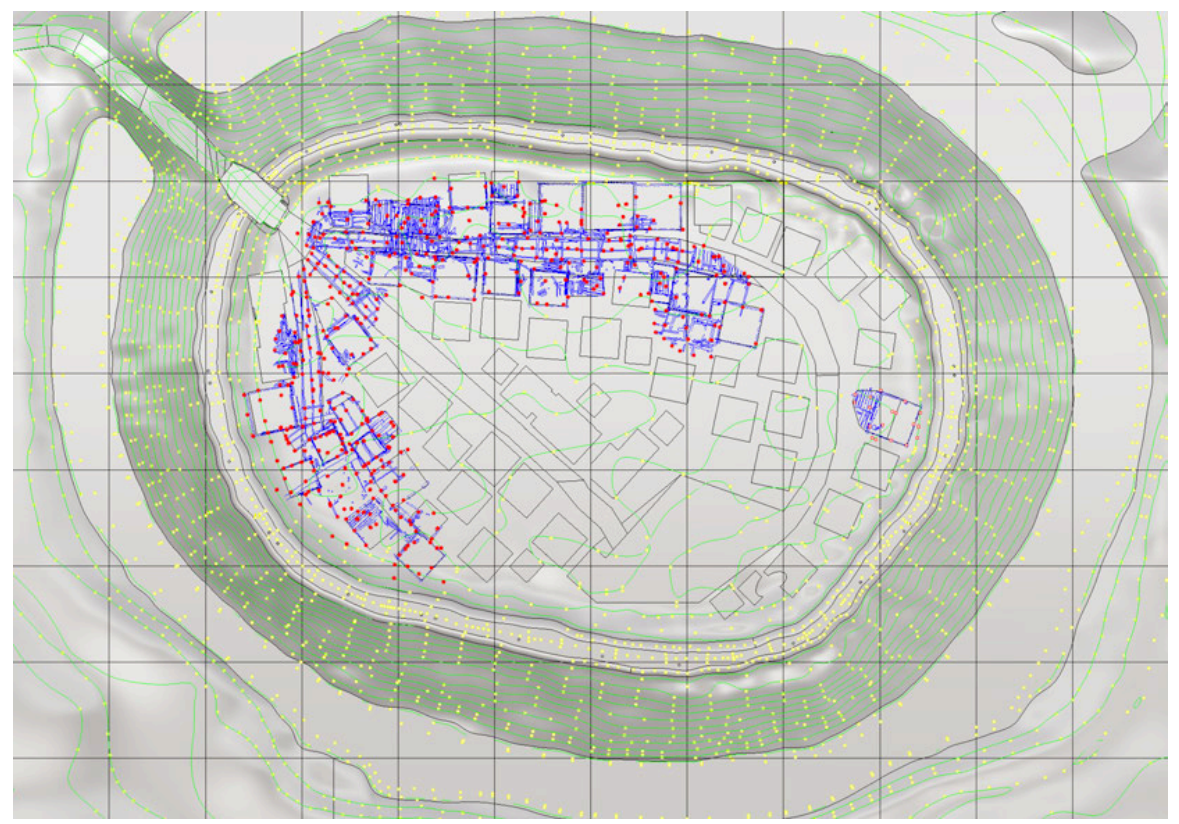

Fig. 3. A 3-dimensional model of terrain based on archaeological and geological data. Blue: relics vector drawing; red: elevation points of archaeological measurement; yellow: points generated by contour lines of the interpolated surface.

In this way, nearly the entire analogue documentation of 140 years of stronghold history, recorded in 17 time-layers, was modeled in 3D, creating spatial representation of found structures. Such representation, even without any further modeling, was a valuable tool for visual analysis of complicated, overlaid, and interrelated structures. This, in turn, allowed reinterpretation, hypotheses, and comprehensive analysis of found artifacts, fulfilling the postulates of virtual archaeology [Pletinckx and Tartessos 2011]. The aforementioned digital model followed principles formulated by Edward C. Harris [Harris 1989], allowing us to relate appropriate diagrams representing stratigraphic sequences to a virtual reconstruction of the site as excavated.

\section{APPLYING PROCEDURAL MODELING FOR THE PULTUSK SITE}

Digital modeling, as applied in the early 1990s in virtual reconstructions of heritage sites, concentrated on visualization of morphology (mainly geometry) in the realm of a virtual world [Alkhoven 1991; Alkhoven 1997; Jacobson and Vadnal 2005; Ennis and Maver 2001]. Procedural modeling concentrates on structural and semantic features of modelled artifacts. Such an approach, 
initially adopted in fine-arts analysis [Stiny and Gips 1972], was subsequently developed in the field of history of architecture [Stiny and Mitchell 1978] and archaeology [Müller et al. 2005]. It also results in defining geometry, but is based on rules derived from knowledge of genetic aspects. These rules may be generalized, as they are an encoded form of knowledge. Where data about a particular artifact or structure is missing, it is possible to classify it within a group characterized by common features possible for description. Another scope of use is where flexibility in derived results is required for achieved results. This includes the hypothesis generation process [Haegler et al. 2009; Saldan 2015]. The following issues of the Medieval settlement in Pultusk can be applied:

- There is insufficient data for some areas, while the others provide information on possible structural solutions; some referential materials from other similar sites are also available [Piekalski 1998]

- $\quad$ There is a need for alternative, dynamic versioning processes allowing verification of hypotheses.

- The relatively long time span of the existence of the stronghold (140 years) requires dynamic placement on a time axis.

These issues justified researching the use of parametric methods to formulate alternative hypotheses for archaeological artifacts found in Pultusk. The interdisciplinary operation allowed us to take advantage of the expert knowledge of both archaeologists and architects. This, in turn, could be used to formulate conclusions for procedural modeling, as well as generated hypotheses verification. Taking into account a few thousand wooden artifacts, procedural modeling was the only method that could be used to achieve our goals in an acceptable time and with reasonable effort. The diagram for the process of reconstruction was prepared (Fig. 4). It serves as a roadmap for a virtual reconstruction process based on initial material gathered during excavations

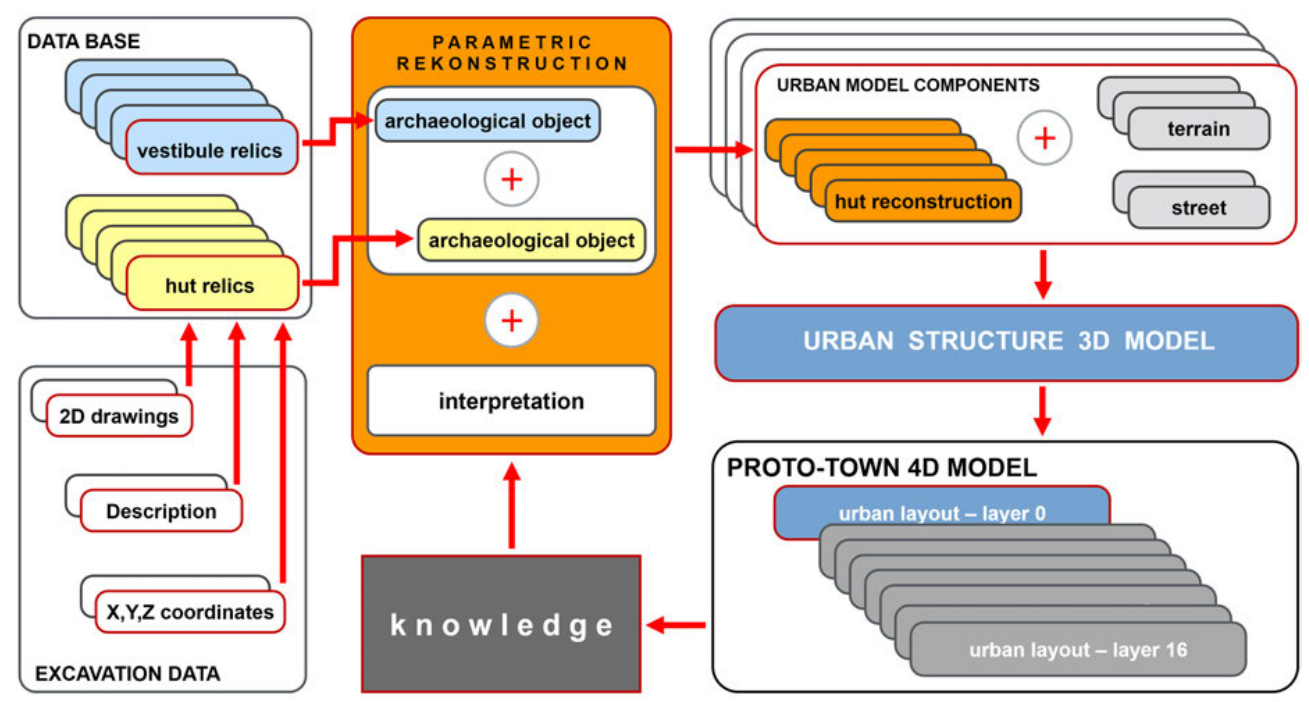

Fig. 4. A schematic diagram of the 4-dimensional reconstruction of the proto-city. Information about artifacts is the basis for development of partial models, which as a result, form a 3-dimensional urban plan. See the description in the text. 
The process started with excavations and exhaustive documentation in an analogue format, which was digitized and collected as a database. The key tool for data arrangement was Harris diagrams, which show the relations between artifacts in excavated layers. This enabled the identification of 17 strata, the definition of the original position of the wooden elements, and the identification of more than 150 objects (huts and vestibules). Methodical analysis allowed the determination of parameters defining the geometric forms of the artifacts. The accepted value of the parameter was determined either directly from the material remains or based on interpretation. In this way, all of the wooden structures that were reflected in the layers were reconstructed using the collected and organized data, in tandem with expert knowledge. These, together with the landscape and street model, served as the basis for a three-dimensional model of urban structure, which allows for the examination of various hypotheses, such as the use of fences and the entrance gate, which is still discussed by archaeologists due to lack of information. The research was carried out on the dependence between 'true' information that comes from excavations and probable information resulting from the synthesis of data and logical thinking. The 'traditional' solid-modeling process helped to define the basic parameters of the palisade, not limited to its average height, which was verified by entrance gate model. The methodology described above was applied to 17 stratigraphic layers (numbered 0 16) to create a prototype 4D model (time-based), a dynamic representation of temporal changes, and developmental hypotheses for settlement.

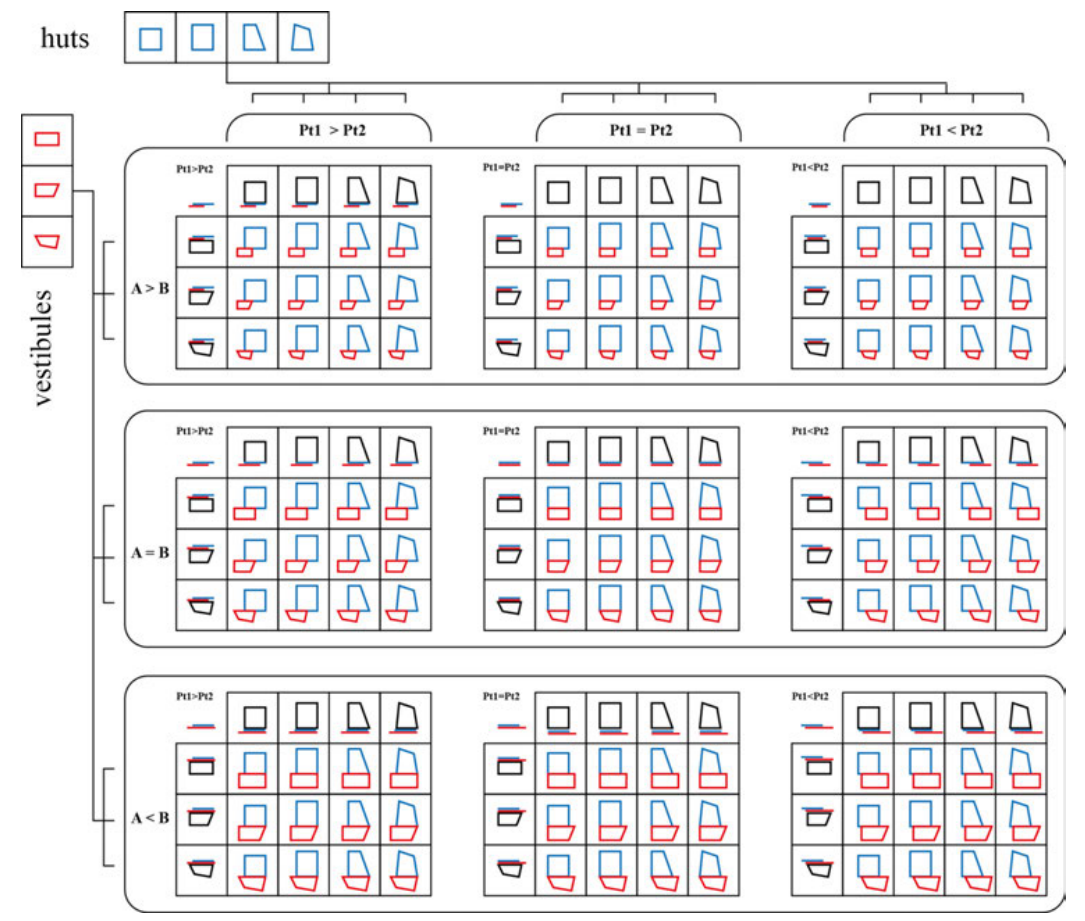

Fig. 5. Shape grammar matrix for relations between hut (blue color) and vestibule position (red color). 64 different variants were established based on two aspects: position and size of elements. Pt 1 represents hut corner point position (coordinate), while Pt2 represents vestibule corner point position. A and $B$ represent size of hut and its vestibule, respectively. 
Archaeological artifacts and interpretations delivered input data for the process of parametric reconstruction. Over 50 parameters were defined to control the form of one hut and its vestibule. They were created on the basis of medieval findings (information from the site), rules of medieval structural methods and urban tissue characteristics (experts' knowledge). This resulted in a matrix of possible solutions used as a base to shape grammar strategy (Fig. 5). A unique interface called 'Pultusk Reconstructor' was developed using Grasshopper for Rhino (Fig. 6), which allows visual control of parameter input. In this way, over 140 huts were built (see examples in Fig. 7). It particularly aided the process of recognition of the original proto-town form in the area where it was not defined by excavations.

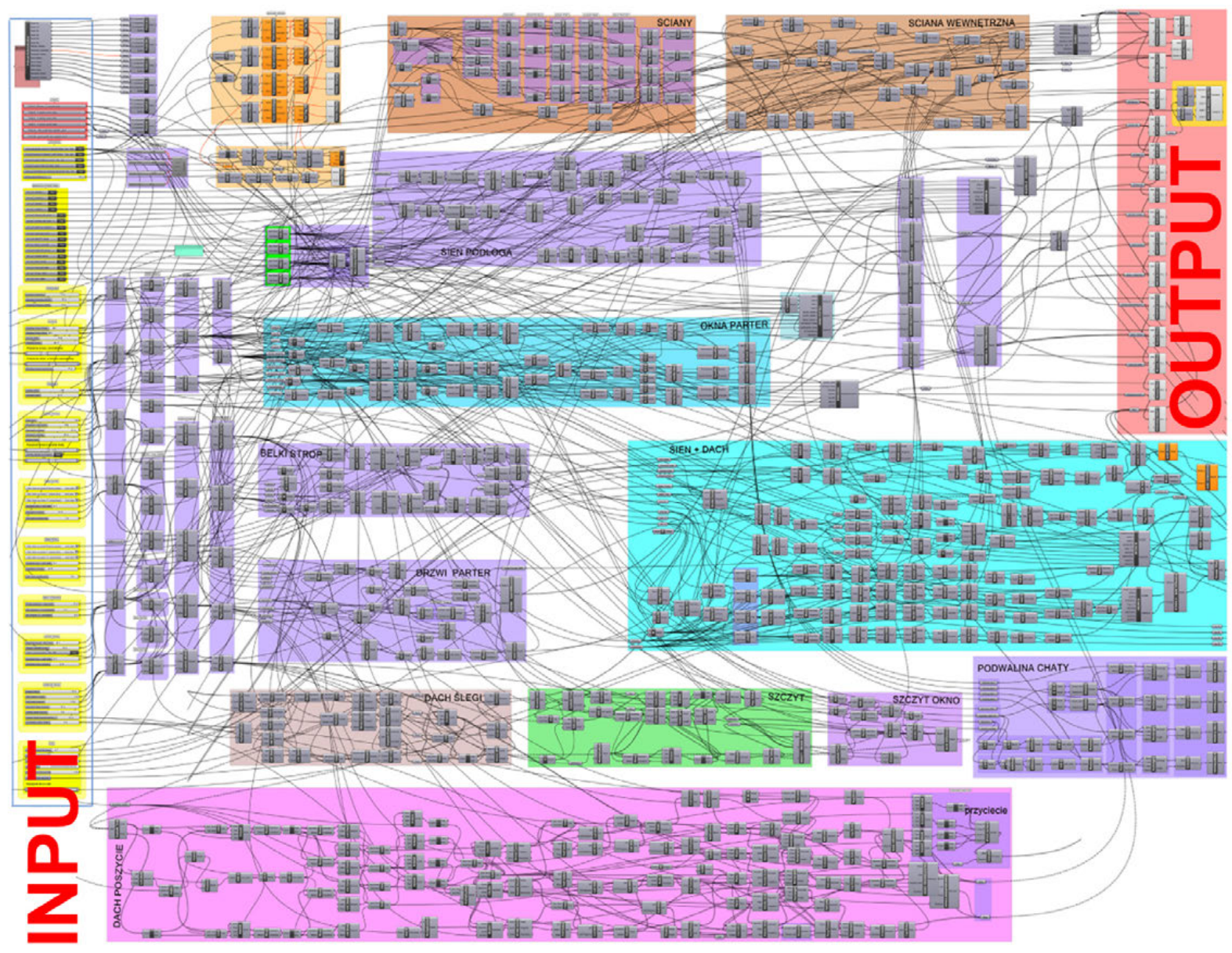

Fig. 6. Grasshopper for Rhino. The application is based on shape grammar rules, controlled by over 50 input parameters (yellow). It generates hut and vestibule construction elements (pink).

The 140-year timespan of the stronghold was also taken into consideration. All 17 time-layers were combined and presented on a time axis, creating a 4D model of Pultusk settlement development (Fig. 8). 


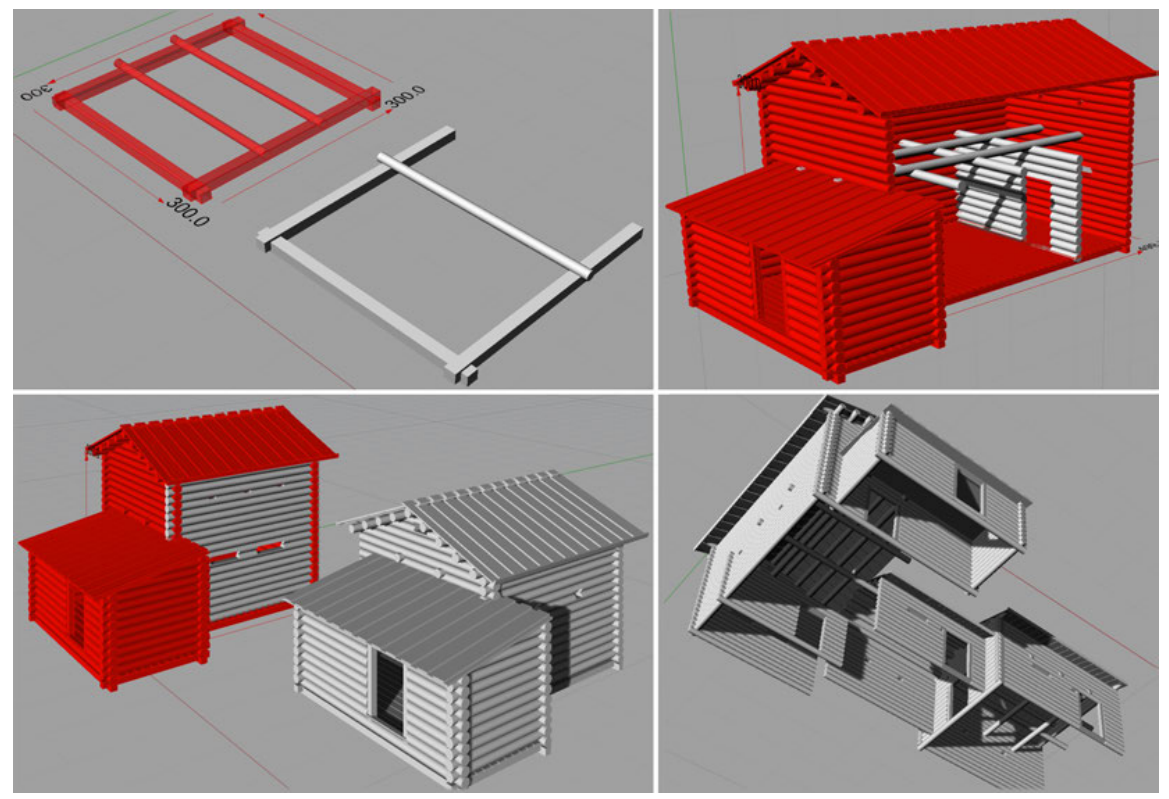

Fig. 7. Example of a hut reconstructed with parametric Pultusk Reconstructor. The simple form of hut and vestibule allows a complex arrangement (bottom - right).

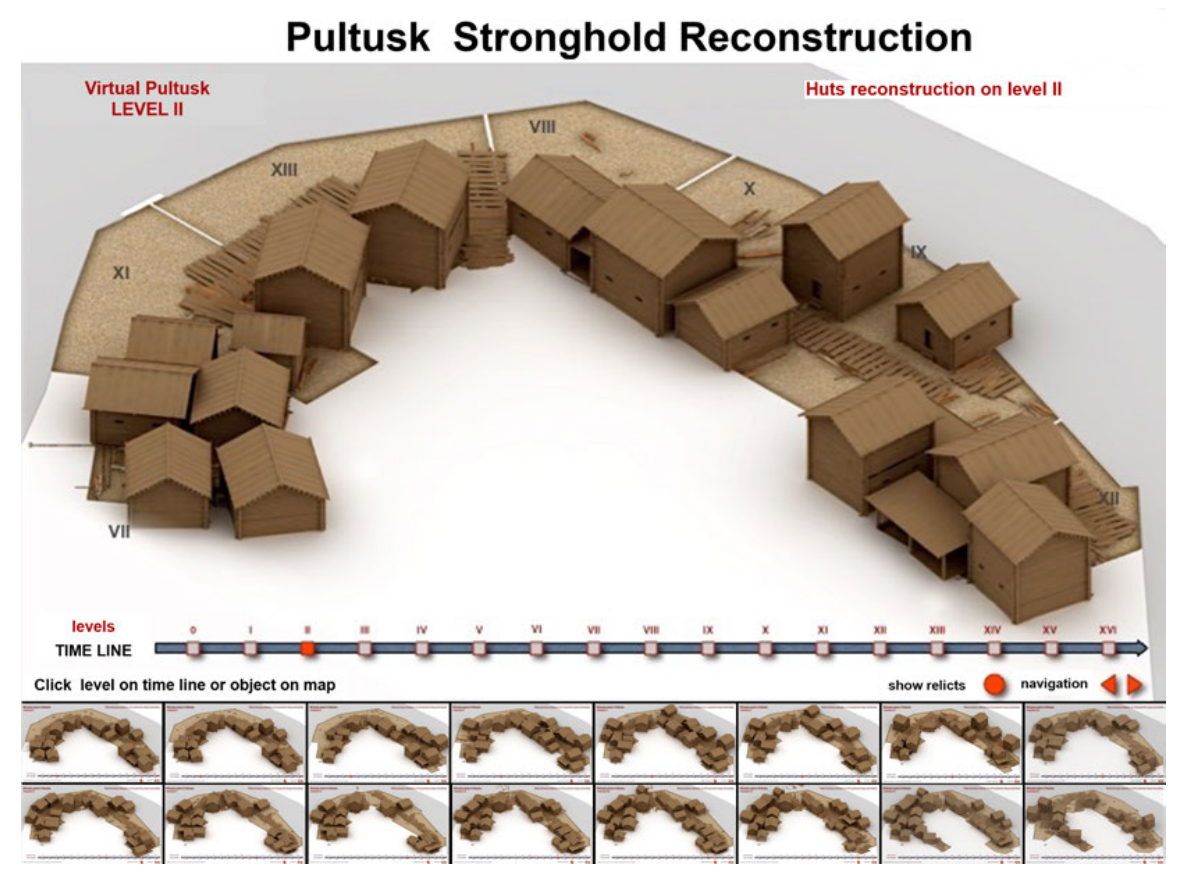

Fig. 8. Huts' reconstruction from 1st level. The Timeline Navigation buttons allow the user to display one of the 16 reconstructed levels. 


\section{MODULAR PHYSICAL MODEL}

An equally important step was taken by the implementation of modular models using 3D printing technology. They not only reflect the similarities in form, but also allow dynamic simulations. An urban model, called Rapid Reconstruction Modular Model (R2M2, scale 1: 100, 120×100 cm in size) was developed as a set of 120 landscape segments $(10 \times 10 \mathrm{~cm})$ corresponding to the archeological matrix of excavations. Swapping segments (or huts) changes the visual result of reconstruction, which generates new findings and interpretations. This implements a flexibility characteristic for virtual reconstructions, especially when using procedural methods, in a physical model. Such a model is the basis of a recently opened exhibition illustrating the history of Pultusk gord in a local museum, thus serving an important role not only as a research tool, but also as a vehicle for dissemination of knowledge and popularization.

A special strategy was also implemented in the physical model due to the data certainty. While all parts of the 3D printed model are originally white, only these reconstructed on the basis of artifacts explored by archaeologists are marked with color (Fig. 9).

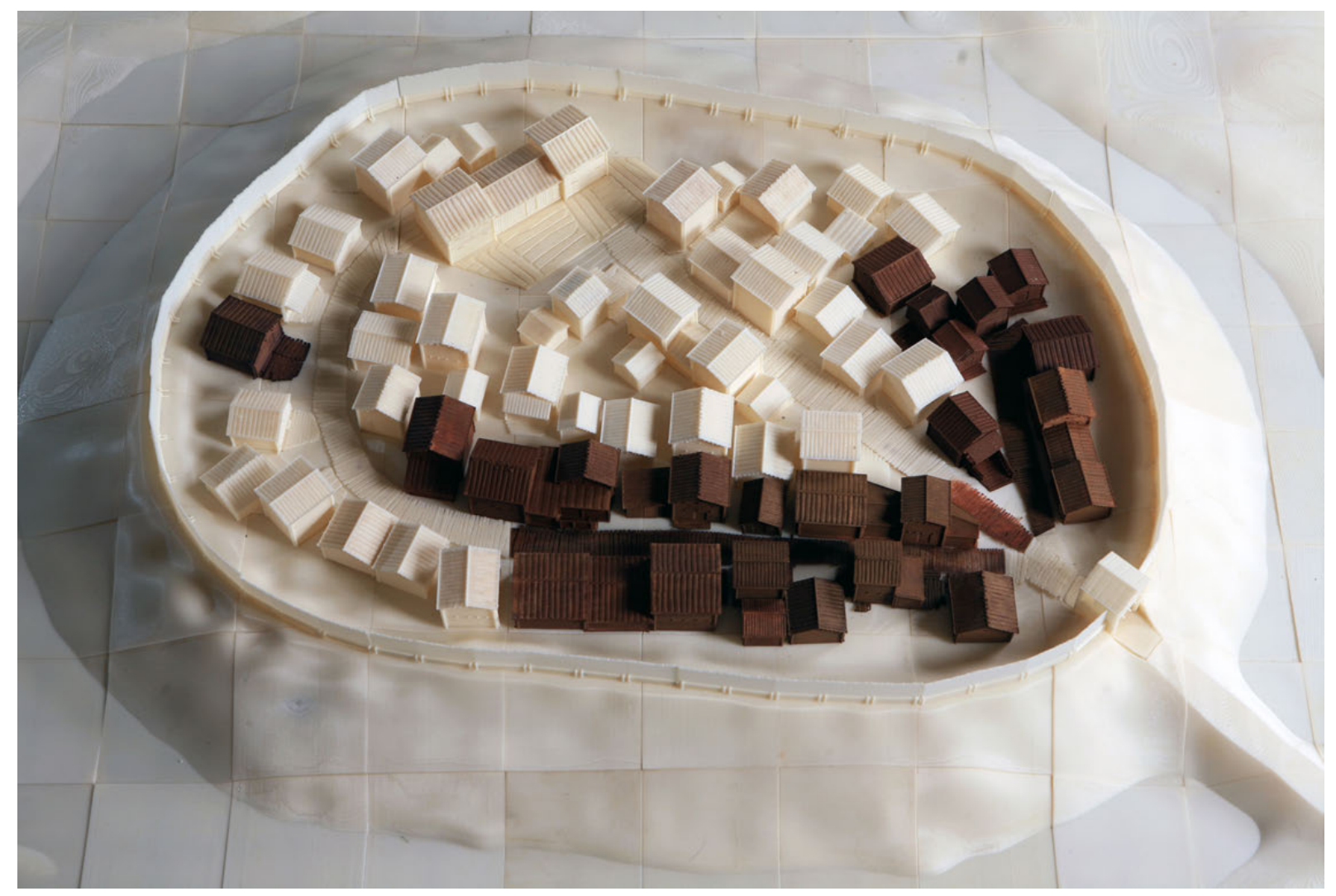

Fig. 9. Proto-city model completed with 3D printing technique. Huts reconstructed on the basis of remains are marked with a brown color. Hypothetical huts are left white. 


\section{CONCLUSIONS}

The reliability of scientific research and the regime of logical reasoning are independent of the technology used, but may be effectively supported by it [Brykowska 2003]. The described case shows the potential of combining analogue records of excavations with 3D virtual terrain and artifact models. Using procedural modeling in the case of the Pultusk excavations and medieval gord reconstruction is an example of such support while maintaining appropriate research standards. In this case, parametric techniques and 3D printing technology have become a platform for dialogue between scientists from different disciplines, facilitating hypothesis verification and visualization of knowledge in the realm of virtual archaeology. In addition, results are considered as dissemination of knowledge. They also bring the forward arguments in favor of continueing archaeological excavations of the remaining $60 \%$ of the proto-city.

The comprehensive sequence of actions that was undertaken may be treated as long-term workflow for reconstructions based on archaeological data available in analogue form:

- archaeological excavations and documentation;

- digitalization of analogue records;

- creation of 3D digital model of archaeological site with all found artifacts;

- deriving sets of rules for procedural modeling based on found structures and experts' knowledge (e.g., Harris matrix);

- creation of procedural models covering hypotheses and changes over time;

- 3D printing of verified physical models;

- using virtual and physical models and renderings as visual research models and as knowledge dissemination tools in museum displays.

Regardless of the form of archaeological data, the essence of the adopted method was to adhere to the principles of archaeological stratigraphy. A Harris matrix of archaeological strata was prepared and used to define relations between relics [Harris 1989]. These relations were re-formed from diagrams into three-dimensional objects whose dimensions were controlled by parameters. Parameter values were taken from an established data system derived from the artifacts. In those areas where excavation data were lacking, a range of parameters based on conclusions-'knowledge' taken from similar excavations of wooden construction-was used. In this case, the value of the parameter had the rank of a hypothesis. A detailed description of the reconstruction process was described in the final publication of the work [Słyk and Wrona 2015].

Results of these actions allow the conclusion that parametric modeling used in cultural heritage reconstructions is a valuable research and knowledge dissemination tool. In some cases, it is indispensable in terms of speed, flexibility, and reliability. Such a tool may be applied in conjunction with traditional methods of recording archaeological excavations, especially in the case of material gathered before digital documentation methods were available.

The effort taken by the research team helped to create the idea of an open-air museum of antiquities located under the castle courtyard. Its implementation would allow the archaeologists to complete 


\section{1:454 K. Koszewski et al.}

the excavations. At the same time, it would provide a main platform for verification of the current research hypotheses. Above all, it would enable a spectacular step in the popularization of knowledge.

\section{REFERENCES}

Patricia Alkhoven. 1997. Computer Visualisation as a Tool in Architectural Historical Research: Representation and Research of the Historical Urban Environment. Archit. Urban Simul. Tech. Res. Educ. (1997), 23-27.

Patricia Alkhoven. 1991. The Reconstruction of the Past : the Application of New Techniques for Visualisation and Research in Architectural History. Archit. Hist. (1991), 549-566.

Maria Brykowska. 2003. Metody pomiarów i badań zabytków architektury, Warszawa: Oficyna Wydawnicza Politechniki Warszawskiej.

Gary Ennis and Tom Maver. 2001. Welcoming multiple visitors to the Virtual City. In Hannu Penttilä, ed. Architectural Information Management: 19th eCAADe Conference Proceedings. Helsinki: Helsinki University of Technology (HUT)/Department of Architecture, 423-429.

A. Gołembnik, D. Makowski, and M. Mierosławski. 1997. Badania na wzgórzu zamkowym w Pułtusku w latach 1976- 1984. In A. Gieysztor, ed. Pułtusk. Studia i materiały z dziejów miasta i rzemiosła, t. III. Pułtusk.

Simon Haegler, Pascal Müller, and Luc Van Gool. 2009. Procedural Modeling for Digital Cultural Heritage. EURASIP J. Image Video Process. 2009, January 2009 (2009), 1-11.

DOI:https://doi.org/10.1155/2009/852392

Edward Harris. 1989. Principles of Archaeological Stratigraphy. Bermuda Marit. Museum 142 (1989), 1001. DOI:https://doi.org/10.1007/s007690000247

Jeffrey Jacobson and Jane Vadnal. 2005. The virtual Pompeii project. Proc. World Conf. E-Learning (2005).

P. Müller, T. Vereenooghe, a Ulmer, and L. Van Gool. 2005. Automatic reconstruction of Roman housing architecture. Rec. Model. Vis. Cult. Herit. (2005), 287-298.

Jerzy Piekalski. 1998. Uwagi o problemie definicji miasta średniowiecznego. In Zofia Kurnatowska, Hanna Kóčka-Krenz, \& Władysław Łosiński, eds. Kraje słowiańskie w wiekach średnich : profanum i sacrum. Poznań: Wyd-wo Poznańskiego Towarzystwa Przyjaciół Nauk, 349-357.

Daniel Pletinckx and Premio Tartessos. 2011. Virtual Archaeology as an Integrated Preservation Method. Virtual Archaeol. Rev. 2 (2011), 33-37.

DOI:https://doi.org/http://dx.doi.org/10.4995/var.2011.4545

Paul Reilly. 1991. Towards a Virtual Archaeology. CAA90. Comput. Appl. Quant. Methods Archaeol. 1990 (1991), 132-139.

Fabio Remondino and Sabry El-hakim. 2006. Image-based 3D modelling: A review. Photogramm. Rec. 21, 115 (2006), 269-291. DOI:https://doi.org/10.1111/j.1477-9730.2006.00383.x

Jeroen De Reu et al. 2013. Towards a three-dimensional cost-effective registration of the archaeological heritage. J. Archaeol. Sci. 40, 2 (2013), 1108-1121.

DOI:https://doi.org/10.1016/j.jas.2012.08.040

Marie Saldan. 2015. An Integrated Approach to the Procedural Modeling of Ancient Cities and Buildings. 30, June (2015). DOI:https://doi.org/10.1093/llc/fqv013 
Jan Słyk and Stefan Wrona. 2015. Informacyjne środowisko rekonstrukcji - przedlokacyjna struktura osadnicza w Pułtusku w XIII-XIV wieku, Warszawa: Oficyna Wydawnicza Politechniki Warszawskiej.

G. Stiny and W.J. Mitchell. 1978. The Palladian grammar.

George Stiny and James Gips. 1972. Shape grammars and the generative specification of painting and sculpture. Inf. Process. 71 Proc. IFIP Congr. 1971. Vol. 271 (1972), 1460-1465.

DOI:https://doi.org/citeulike-article-id:1526281

Received March 2017; revised July 2017; accepted August 2017. 